\title{
CAPTURING THE INEFFABLE
}

An Anthropology of Wisdom 
This page intentionally left blank 


\section{Capturing the Ineffable}

An Anthropology of Wisdom

EDITED BY PHILIP Y. KAO

AND JOSEPH S. ALTER

UNIVERSITY OF TORONTO PRESS

Toronto Buffalo London 
(C) University of Toronto Press 2020

Toronto Buffalo London

utorontopress.com

Printed in Canada

ISBN 978-1-4875-0313-0 (cloth) ISBN 978-1-4875-1726-7 (EPUB)

ISBN 978-1-4875-1725-0 (PDF)

\section{Library and Archives Canada Cataloguing in Publication}

Title: Capturing the ineffable : an anthropology of wisdom / edited by Philip Y. Kao and Joseph S. Alter.

Names: Kao, Philip, editor. I Alter, Joseph S., editor.

Description: Includes bibliographical references and index.

Identifiers: Canadiana (print) 20200177745 | Canadiana (ebook)

20200177796 | ISBN 9781487503130 (cloth) | ISBN 9781487517267

(EPUB) I ISBN 9781487517250 (PDF)

Subjects: LCSH: Wisdom. I LCSH: Anthropology.

Classification: LCC BD450 .C37 2020 | DDC 301.01 - dc23

Funding for the research project on wisdom and aging and a conference entitled "Capturing the Ineffable: Wisdom in Perspective" provided by the Office of the Provost, University of Pittsburgh.

University of Toronto Press acknowledges the financial assistance to its publishing program of the Canada Council for the Arts and the Ontario Arts Council, an agency of the Government of Ontario.

Canada Council for the Arts

Conseil des Arts du Canada

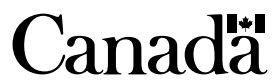

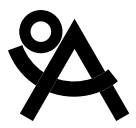

ONTARIO ARTS COUNCIL CONSEIL DES ARTS DE L'ONTARIO

an Ontario government agency un organisme du gouvernement de l'Ontario 